\title{
ARTICLE \\ Empirical exploration of remittances and renewable energy consumption in Bangladesh
}

\author{
Anupam Das $^{1}$ (D) $\cdot$ Adian McFarlane $^{2} \cdot$ Luc Carels $^{1}$
}

Received: 29 April 2020 / Accepted: 9 November 2020 / Published online: 3 January 2021

(C) The Japan Section of the Regional Science Association International 2021

\begin{abstract}
In recent years, a surge of remittances to Bangladesh has enabled rural households to adopt modern renewable energy sources. However, researchers have yet to examine any statistical association between remittances and renewable energy. In this study, we determined the causal relationships between per capita remittance inflows and renewable energy consumption in Bangladesh using annual data for the period 1980-2017. This is the first such study. This determination was made while controlling for changes in GDP, and employing causality and cointegration testing. We arrived at three key results. First, a unidirectional causality running from the level of remittances per capita to a level of renewable energy consumption was determined. Second, we observed a unique cointegrating relationship between the variables. Third, a short-run bidirectional causality between remittances per capita and renewable energy consumption was clarified. Important policy implications indicate that the government should create incentives for remittance-recipient households to invest remittance funds in modern renewable technologies such as solar home energy systems.
\end{abstract}

Keywords Remittances $\cdot$ Renewable energy consumption $\cdot$ Causality $\cdot$ Cointegration

Anupam Das

adas@mtroyal.ca

Adian McFarlane

amcfar22@uwo.ca

Luc Carels

1care938@mtroyal.ca

1 Department of Economics, Justice, and Policy Studies, Mount Royal University, Calgary, AB, Canada

2 School of Management, Economics, and Mathematics, King's University College At Western University Canada, London, ON, Canada 


\section{Introduction}

Over the past several decades, remittance inflows have proven to be an important and perhaps economically necessary source of revenue for developing countries. As of 2018, total global remittance inflows to developing countries crossed the USD 500 billion mark (World Bank 2019a). This is more than the total global official development assistance to developing countries. Since the early 1980s, remittances have been an important source of foreign currency in Bangladesh. Total remittance inflows to Bangladesh amounted to USD 15.6 billion in 2018, which accounted for $5.7 \%$ of GDP and more than three times the combined amount of official development assistance and foreign direct investment (World Bank 2020). This was up from USD 0.78 billion (less than 2.6\% of GDP) in 1990. Currently, Bangladesh is one of the top ten remittance-recipient countries in the world (World Bank 2019b). Since 1990, Bangladesh's economy has seen a concomitant expansion, as GDP per capita was USD 306 in 1990, but increased to just shy of USD 1700 by 2018. Similarly, energy consumption has also increased from $123.5 \mathrm{~kg}$ of oil equivalent (koe) in 1990-229.2 koe in 2014 (World Bank 2020).

While researchers have extensively studied the remittances' impact on economic growth and other socioeconomic factors, few have studied the relationship between remittances and energy consumption. Given remittances supplement personal income, it can be theorized that remittances could increase energy consumption directly through the expenditure of remittance income in an effort to improve living standards. Thus, understanding the relationship between remittance and energy consumption is of some importance. Moreover, remittances could increase the energy consumption indirectly through increased economic activity, through the formation of human capital (Adams and Cuecuecha 2013), or through increased financial capital (Senbeta 2013). In fact, Akçay and Demirtaş (2015) found for Morocco that remittances increased energy consumption, because remittances increased income levels which increased demand for energy. A recent study by Das and McFarlane (2020) examined the relationship between remittances and the consumption of disaggregated non-renewable energy sources (for example, natural gas, coal, and petroleum) in Bangladesh. They found a long-run bidirectional relationship between remittances and natural gas consumption, a unidirectional relationship running from coal consumption to remittances, and a unidirectional relationship from remittances to petroleum consumption. Our paper departs from Das and McFarlane (2020) by examining the association between remittances and renewable energy consumption for Bangladesh.

Researchers have long recognized the importance of the use of renewable energy in fighting climate change (Inglesi-Lotz 2016; Kula 2014; Tiwari 2011). According to the World Disasters Report 2018 (International Federation of Red Cross and Red Crescent Societies 2018), Bangladesh is the eighth worst affected country in the world in terms of the number of people affected by natural disasters in the last 10 years. Geographical and climate related attributes make Bangladesh vulnerable to natural disasters (Hossain et al. 2020). Only in the last decade, the Government of Bangladesh (2008) adopted the Renewable Energy Policy of Bangladesh to 
address the declining fossil fuel availability and to mitigate climate change. Since 2003, Bangladesh's success in building the largest national off-grid electrification program in the world has been unprecedented (Sadeque et al. 2014). Within the next decade, more than 3 million rural homes in Bangladesh were connected with the off-grid solar home systems (Khandker et al. 2014). Although the share of renewable to total energy has shown a steady decline in recent years, modern renewable energy sources, such as solar power, have become more popular in recent years (U.S. Energy Information Administration 2020; Islam 2018). Lack of income is still a challenge; however, Sadeque et al. (2014) argued that the influx of international remittances has made it possible for rural households to adopt solar home systems.

Despite some anecdotal evidence that remittances potentially impact renewable energy consumption in Bangladesh, empirical work on this issue is conspicuously absent. The objective of our paper is to identify how remittances and renewable energy consumption are interlinked in Bangladesh. To date, only one paper by Das and McFarlane (2020) examined the relationship between remittances and energy consumption in Bangladesh. No study has yet established the potential link between renewable energy consumption and remittances. We aim to fill this void in the literature by answering this question: What are the causal relations between remittances per capita and renewable energy consumption allowing for changes in macroeconomic conditions as reflected in changes in GDP per capita? To answer this question, we use annual Bangladeshi data that span the period 1980-2017. We employ the break-point unit root tests, vector autoregression (VAR)-based Toda-Yamamoto causality test, Johansen cointegration test, and Granger causality test from a vector error correction modeling (VECM) framework. These techniques were widely used by several authors to examine the relationships between energy consumption and other macroeconomic variables (Benali and Feki2020; Rehman et al. 2019; Iyke 2015; Shahbaz and Lean 2012; Wang et al. 2011; Oh and Lee 2004a, b). Our paper is novel for three reasons. First, to our knowledge, this is the only paper that makes an attempt to understand how remittances and renewable energy consumption interact in one of the highest remittance-recipient economies in the world. Second, we examine both short-run and long-run dynamics between these variables while controlling for changes in economic conditions. Third, our results will have several policy recommendations that are not only important for Bangladesh but also for other remittance-recipient developing countries.

To preview, we find three important results. First, the Toda-Yamamoto causality test indicates a unidirectional causality from the level of remittances per capita to the level of renewable energy consumption. Second, from the Johansen cointegration test, there is a cointegrating equilibrium relationship among the variables. And third, from the VECM, we find evidence of a bidirectional short-run causality between remittances per capita and renewable energy consumption. We organize the rest of the paper in the following manner. Section 2 provides the literature review. Section 3 presents the data and econometric methods. Section 4 presents the empirical findings. Section 5 provides concluding remarks, offers policy recommendations, and the scope for future research. 


\section{Review of the existing literature}

\subsection{Macroeconomic impacts of remittances in Bangladesh}

Since the 1980s, scholars have recognized that remittance inflows and policies relating to them have an important role to play in achieving the macroeconomic goals of economic growth, external balance, full employment, and stable inflation for developing countries (e.g., Akter 2018; Chimhowu et al. 2005; Orozco 2005; Glytsos 1993; Glytsos 2002; Russell 1986; Stahl and Arnold 1986; Stahl and Habib 1989). For Bangladesh, a survey of the literature reveals that many scholars have examined the impact of remittances on consumption and by extension economic growth. For example, Mamun and Nath (2010) found that remittances tend to increase household consumption. Stahl and Habib (1989) demonstrated that remittances were mainly used for different types of consumption. Das (2012) found that, in the short run, approximately $58 \%$ of all remittances inflows to Bangladesh were used for consumption. Barai (2012) argued that remittances caused an increase in the marginal propensity to consume. Similarly, Azam (2015) found that remittances increase economic growth through an increase in aggregate expenditures. Finally, using timeseries data from 1976 to 2015 and applying autoregressive distributed lags (ARDL) bounds test to cointegration in order to factor in reverse flows, Das and Chowdhury (2019) estimated that $49 \%$ of remittances went directly to financing consumption in the long run.

Some scholars also found that remittance inflows run counter to macroeconomic objectives in Bangladesh. For example, Khan and Islam (2013) found that remittances increased the long-run inflation rate in Bangladesh. Thus, the real-purchasing power out of remittances may be much smaller than what would otherwise expect from a positive remittance-consumption nexus. An increase in inflation due to a rise in remittances may potentially reduce all consumption including energy consumption. Chowdhury and Rabbi (2014) found that remittances appreciated the real exchange rate which harmed Bangladesh's export sectors. In such a situation, the ultimate growth effect of remittances would be much smaller. Furthermore, Hassan et al. (2016) found evidence of a $U$-shaped relationship between remittances to Bangladesh and economic growth. In this case, remittances must reach a certain threshold level before their ultimate effect can be realized.

Studies on the impacts of remittances on macroeconomic variables for Bangladesh have also demonstrated that there is no agreement on which direction the relationship runs. Hasan (2008) argued that the economic conditions of the remittancerecipient country can impact remittance inflows. Specifically, interest rates and GDP have a positive relationship with remittance inflows, while inflation rates have a negative impact. Rahman (2009) found only a short-run causal relationship running from remittances to real GDP from 1976 to 2006. Paul et al. (2011) provided evidence for the causal relationship running from economic growth to remittances from 1976 to 2010 . They argued that as the economy grew, more opportunities became available which increased the demand for remittances. Chowdhury (2011) found a positive impact of remittances on enhancing the financial sector of Bangladesh. 
Chowdhury used the ratio of private domestic deposits to GDP, bank credit to GDP, and money supply to GDP to measure the development of Bangladesh's financial sector. The dataset for this study covered the 1971-2008 period. The conclusion was that remittance inflows increased economic growth by strengthening investment. However, Akçay (2020) argued that remittances impacted financial development in Bangladesh only when it reaches an inflection point. The threshold level of remittances is between 7 and 8\% of GDP. Siddique et al. (2012) used unit root, cointegration, and causality tests to show that there was a unidirectional causality from remittances to economic growth from 1976 to 2006. Hossain and Hasanuzzaman (2013) found that remittances had a positive impact on gross fixed capital income. Finally, Kumar and Stauvermann (2014) discovered a bidirectional relationship between per capita output and per capita remittances from 1979 to 2012. Thus, as with so much of the macroeconomic literature around the impact of remittances, there is a lack of clarity as to their impacts. Therefore, additional studies are warranted before designing remittance-specific policies in Bangladesh.

\subsection{Potential links between remittances and renewable energy consumption}

Two major global events have served to focus the attention of policymakers and academics on the relationship between economic growth and energy consumption. The first of these was the 1973 oil crisis. The dramatic spike in the price of oil and energy shortages across the globe caused concern about how this would impact economic growth. The second of these events occurred much more recently. The increasing global concern about the environmental sustainability of energy production and consumption has led to similar concerns about what impact the reduction of non-renewable energy consumption and the switch to more renewable forms of energy could have on economic growth. The implications are fundamental to future environmental policy. If the switch to renewable energy sources significantly reduces economic growth, the efficacy of such a change is called into question. The saliency of this policy issue is only increased by the fact that global economic growth remains low even a decade after the onset of the Great Recession. With growing public and consumer debt, a few countries can afford to further slow economic growth.

Several scholars have examined the causal relationship between GDP growth and energy consumption (Mahalingam and Orman, 2018; Menegalo and Ozturk, 2016; Al-Mulali et al., 2013; Borozan, 2013; Menegakia, 2011; Menyah and WoldeRufael, 2010). As these studies show, there is no agreement in the literature on how these two variables interact and what policy prescriptions can be made from these studies. The findings from these scholars can be grouped into four hypotheses. The first is the growth hypothesis where the direction of causality flows from energy consumption to GDP growth. The conservation hypothesis is the second. Here, causality runs from GDP growth to energy consumption. The third is the bidirectional causality between energy consumption and GDP growth, i.e., the feedback hypothesis. Finally, the fourth is the neutrality hypothesis when GDP and energy consumption do not exhibit any causal relationship. All four hypotheses received at least some empirical support. The differences in the findings from these hypotheses emerge 
from a number of factors including heterogeneity across countries and regions, time periods used in these papers, and differences in statistical methods applied to these studies.

The policy implications of understanding which hypothesis holds became particularly important in the 1970s, in response to the first oil crisis in 1973. If the conservation hypothesis held, then a country could embark on a policy to reduce energy consumption without being overly concerned about the impacts of such a policy on economic growth. On the other hand, if the growth hypothesis held, then sustained consumption of energy would be important in order for a country to maintain economic growth. If it were the feedback hypothesis that held, then this would provide policymakers with increased flexibility and policy options due to the complementary nature of GDP growth and energy consumption. In the case of the neutrality hypothesis, to increase economic growth policymakers must look for options outside of increasing energy consumption. In the case of Bangladesh, the growth hypothesis received support from Masuduzzaman (2012) and Alam and Sarker (2010) as it relates to electricity generation. Alam et al. (2012) found the same for energy consumption in general. In these papers, the authors showed that the causation primarily runs from energy consumption to economic activity.

Conversely, Mozumder and Marathe (2007) found support for the conservation hypothesis for electricity consumption, while Paul and Uddin (2011) demonstrated that the conservation hypothesis held for total energy consumption. Das et al. (2013) studied the relationship between natural gas consumption and GDP, and found evidence for the conservation hypothesis. Alam et al. (2017) found the conservation hypothesis held for non-renewable energy consumption. These papers found some evidence of unidirectional causality from economic growth to different types of energy consumption. Ahamad and Islam (2011) found evidence for the feedback hypothesis. Recently, Dey and Tareque (2019) also found the feedback hypothesis to hold in the long run. In summation, one can argue that there is significant disagreement, even within the same country, about the relationship between energy consumption and economic growth.

The aforementioned four hypotheses can be used to posit an explanation of the macroeconomic impacts of renewable energy consumption. The literature on the empirical relationships between renewable energy consumption and GDP is vast. Table 1 presents a summary of some of the findings published in the last decade. Several important observations stand out from the existing literature. First, with the exception of Chen et al. (2019), Bulut and Muratoglu (2018), Amri (2017), BenSalha and Sebri (2014), Pao et al. (2014), Ocal and Aslan (2013), and Sadorsky (2009), other studies focus on examining the relationship between renewable consumption and economic growth in developed countries. However, policy implications that emerge from these findings may not apply in developing countries, which are structurally different from developed countries. For example, due to resource constraints, many developing countries develop their renewable energy sector much later than their developed counterparts. In fact, Chen et al. (2020) showed that the relationship between renewable energy consumption and economic growth could be non-linear. There is evidence of a positive linear effect of renewable energy consumption on economic growth in OECD countries. Developing countries only 
Table 1 Summary of the results on the relationship between renewable energy and GDP

\begin{tabular}{llll}
\hline Author (year) & Country/region & Study period & Causal direction \\
\hline Chen et al. (2019) & China & $1995-2012$ & Y $\leftrightarrow$ RE \\
Bulut and Muratoglu (2018) & Turkey & $1990-2015$ & No causality \\
Amri (2017) & Algeria & $1980-2012$ & RE $\rightarrow \mathrm{Y}$ \\
Alper and Oguz (2016) & EU & $1990-2009$ & $\mathrm{RE} \rightarrow \mathrm{Y}$ \\
Bhattacharya et al. (2016) & 38 renewable energy consuming & $1991-2012$ & $\mathrm{RE} \rightarrow \mathrm{Y}$ \\
& countries & & \\
Inglesi-Lotz (2016) & OECD & $1990-2010$ & $\mathrm{RE} \rightarrow \mathrm{Y}$ \\
Saidi and Mbarek (2016) & 9 developed countries & $1990-2013$ & $\mathrm{RE} \rightarrow \mathrm{Y}$ \\
Apergis and Payne (2014) & OECD & $1980-2011$ & $\mathrm{Y} \leftrightarrow \mathrm{RE}$ \\
Ben-Salha and Sebri (2014) & Tunisia & $1971-2010$ & $\mathrm{Y} \leftrightarrow \mathrm{RE}$ \\
Kula (2014) & OECD & $1980-2008$ & $\mathrm{Y} \rightarrow \mathrm{RE}$ \\
Pao et al. (2014) & MIST (Mexico, Indonesia, South & $1990-2010$ & $\mathrm{RE} \rightarrow \mathrm{Y} / \mathrm{RE} \leftrightarrow \mathrm{Y}$ \\
& Korea, Turkey) & & \\
Salim et al. (2014) & OECD & $1980-2011$ & $\mathrm{Y} \rightarrow \mathrm{RE}$ \\
Ocal and Aslan (2013) & Turkey & $1990-2010$ & $\mathrm{Y} \rightarrow \mathrm{RE}$ \\
Apergis and Payne (2012) & World & $1990-2007$ & $\mathrm{Y} \leftrightarrow \mathrm{RE}$ \\
Yildirim, Saraç, and Aslan (2012) & USA & $1949-2010$ & No causality \\
Apergis and Payne (2011) & Central America & $1980-2006$ & $\mathrm{Y} \leftrightarrow \mathrm{RE}$ \\
Menegaki (2011) & Europe & $1997-2007$ & No causality \\
Apergis and Payne (2010) & Eurasia & $1992-2007$ & $\mathrm{Y} \leftrightarrow \mathrm{RE}$ \\
Bowden and Payne (2010) & USA & $1949-2006$ & $\mathrm{RE} \leftrightarrow \mathrm{Y} / \mathrm{RE} \rightarrow \mathrm{Y}$ \\
Payne (2009) & USA & $1949-2006$ & No causality \\
Sadorsky (2009) & 18 emerging economies & $1994-2003$ & $\mathrm{Y} \rightarrow \mathrm{RE}$ \\
\hline (1) & & & \\
\hline
\end{tabular}

(1) $\mathrm{Y}=$ Some form of national income; RE $=$ renewable energy. (2) $\rightarrow$ and $\leftrightarrow$ imply unidirectional and bidirectional causality respectively

realize the benefits of renewable energy consumption after a threshold level. Therefore, the immediate relationship between renewable energy consumption and other macroeconomic variables may not be apparent in the empirical findings.

Second, it is not clear in the existing literature how remittances can affect the consumption of renewable energy in developing countries. Many households in these countries supplement their income with remittances. A significant rise in remittance inflows in recent decades to developing countries not only helped households expand their consumption bundle, but many households also increased their demand for renewable energy. Mendelson (2013) claimed that there was an increasing trend to use remittances to finance renewable energy projects. However, the only evidence given is of the Multilateral Investment Fund's program that allowed those sending remittances to Haiti to instead finance renewable energy products. At the time, this program had helped to finance over 30,000 solar lanterns. The Nordic Development Fund (2015) claimed that 150 solar water heaters have been sold as a result of a project designed to encourage Bolivian migrants in Spain to use some of their remittance income on cleaner energy products. Similar ideas were explored by the 
International Fund for Agricultural Development (2016), who recommended that governments should support remittance-recipient families to invest in cleaner energy sources. The Swiss Agency for Development and Cooperation (2018) claimed that remittances played an important role in delivering renewable energy technologies in developing countries. However, all these claims were anecdotal and have never been tested with any empirical data.

In this regard, Bangladesh is a success case. While discussing the success stories of the solar home systems in Bangladesh, Khandker et al. (2014) noted "Rapid solar home systems expansion in Bangladesh to some 3 million rural households by early 2014 has drawn the attention of donors and governments of other countries. Phenomenal coverage within such a short period of time has been made possible, in part, by the subsidy provided by donors to facilitate solar home systems adoption in remote and off-grid areas" (pp. 4). Mahmud (2016) and Sadeque et al. (2014) argued that remittance flows increased the demand for solar home systems, and this additional demand has played an instrumental role in the success of solar home systems. Nonetheless, no empirical work has yet proved the association between remittances and renewable energy consumption in developing countries, let alone Bangladesh.

The first empirical work on the relationship between total energy consumption and remittances came from Akçay and Demirtaş (2015) who analyzed data from Morocco from 1975 to 2000, and found that remittance inflows and energy consumption were self-reinforcing. This work was followed by Das and McFarlane (2020), who examined the relationship between remittances and disaggregated non-renewable energy consumption in Bangladesh. They suggested four possible relationships between these variables in line with the four aforementioned hypotheses in regard to the relationship between GDP growth and energy consumption. First, since remittances may expand one's fiscal capacity to consume, there could be a unidirectional relationship from remittances to energy consumption. Second, if remittances are not permanent inflows, recipients of remittances (i.e., immediate or extended family members) may save the extra cash instead of spending it. In this case, the relationship between remittances and energy consumption would be statistically insignificant. Third, the relationship could flow unidirectionally from energy consumption to remittances, because increased consumption may increase demand for remittances. Fourth, the relationship could be bidirectional in that remittances and energy consumption would reinforce each other. Theoretically, the same four possibilities can be applied to understand the potential relationships between renewable energy consumption and remittances. If the anecdotal evidence from Bangladesh holds (i.e., the flow of remittances expands the consumption of renewable energy consumption), one would expect a causal relationship between remittances and renewable energy consumption. The large flow of remittances coupled with the success story in the renewable energy sector makes Bangladesh an interesting case to study the causal relationship between remittances and renewable energy consumption. 


\section{Empirical strategy}

\subsection{Data}

The primary distinction between renewable and non-renewable sources of energy is the rate at which a given resource is consumed relative to the rate at which it is produced. For example, oil is a non-renewable source of energy, because an oil reserve is consumed faster than a new one can be formed. Thus, non-renewable sources of energy can be characterized by their finite quantity. In this study, we use annual data over the period 1980-2017. We collected the data from the World Bank (2020) and U.S. Energy Information Administration (2020).

Remittance inflows are measured in 2010 constant US dollar. These flows are household income that are generated by economic activity outside of the domestic economy that are in turn remitted (transferred to or earned by) by the households in the domestic economy. There are three main categories that make up remittance inflows. These categories are personal remittances (e.g., cash in kind, income from employment in other economies or non-resident entities in the domestic economy, etc.), social benefits (e.g., pension payments, insurance payments, etc.), and current and capital transfers to non-profit institutions serving households in the domestic economy from private and public non-profit international organizations. ${ }^{1}$ We control for the macroeconomic activity by including GDP in our analysis. GDP is also measured in 2010 constant US dollar. Both remittances and GDP are divided by the population of Bangladesh to convert the variables to their per capita amount. Renewable energy consumption is defined as the consumption of energy from sources that are naturally replenishing. This variable is measured in quadrillion British thermal units (Btu). We transform all three variables by taking their natural logarithm. We denote the log-transformed renewable energy consumption, remittance per capita, and GDP per capita as $L N R E, L N R E M$, and $L N G D P$ respectively. $^{2}$

\subsection{Methods}

Our empirical method proceeds as follows. First, we check for the maximal orders of integration of $L N R E, L N R E M$, and $L N G D P$ using the standard Augmented Dickey Fuller (ADF) and Phillips-Perron (PP) unit root tests. In addition, we also report the ADF break-point unit root tests. Second, we use the VAR causality testing framework of Toda and Yamamoto (1995). ${ }^{3}$ The basis of using this VAR testing framework is that it is a lag-augmented approach based on possibly integrated processes, such that the determination of causality, in the Granger sense, is valid irrespective of the orders of the integration of the variables and whether or not they

\footnotetext{
1 See the following glossary for further details: https:/ec.europa.eu/eurostat/statistics-explained/index .php?title $=$ Glossary:Remittances.

${ }^{2} L N R E$ is the natural $\log$ of renewable energy consumption, LNREM is the natural $\log$ of per capita remittances, and $L N G D P$ is the natural $\log$ of real GDP.

3 See also Toda and Phillips (1994) and Dolado and Lütkepohl (1996).
} 
are cointegrated. In this approach, a VAR in levels is initially estimated for $L N R E$, LNREM, and LNGDP as shown below:

$$
\begin{gathered}
\operatorname{LNRE}_{t}=k_{1}+\sum_{i=1}^{p+d} \alpha_{1 i} L_{N R E_{t-i}}+\sum_{i=1}^{p+d} \beta_{1 i} L N G D P_{t-i}+\sum_{i=1}^{p+d} \gamma_{1 i} L_{N R E M_{t-i}}+e_{1} \\
L N G D P_{t}=k_{2}+\sum_{i=1}^{p+d} \alpha_{21 i} L N R E_{t-i}+\sum_{i=1}^{p+d} \beta_{2 i} L N G D P_{t-i}+\sum_{i=1}^{p+d} \gamma_{2 i} L_{N R E M_{t-i}} e_{2} \\
\operatorname{LNREM}_{t}=k_{3}+\sum_{i=1}^{p+d} \alpha_{3 i} L_{N R E_{t-i}}+\sum_{i=1}^{p+d} \beta_{3 i} L N G D P_{t-i}+\sum_{i=1}^{p+d} \gamma_{3 i} L_{N R E M_{t-i}}+e_{3}
\end{gathered}
$$

In this VAR, the first $p$ lags are treated as endogenous and the last $d$ lags as exogenous. The latter, i.e., $d$ lags, represents the maximal differencing required to make LNRE, LNREM, and LNGDP stationary. The starting values of the first $p$ lags are chosen on the basis of information criteria, namely Akaike's information criterion, Schwarz's Bayesian information criterion, and the Hannan and Quinn information criterion. These lags are subsequently adjusted, so that the final $p+d$ lags produce a VAR that is internally valid. Specifically, the VAR must be dynamically stable (all eigenvalues in modulus less than one) with residuals that are serially uncorrelated (assessed with Lagrange Multiplier test) and multivariate normally distributed (assessed with Jarque-Berra test). With a VAR that is internally valid, the Toda and Yamamoto causality testing assesses precedence for first $p$ endogenous lags only using a Wald chi-squared test for exclusion.

The third and final step of our empirical strategy is to check for the existence of causal relations from a cointegrating equilibrium perspective using the Johansen methodology. This is a sort of reinforcement and cross check of the previous causality testing. This is so because if there is cointegration then there should be one-way or two-way causality among the variables from VAR causality testing (Clarke and Mirza 2006; Zapata and Rambaldi 1997). In the Johansen methodology, we use the trace and maximum-eigenvalue sequential testing approach. The null hypothesis of the trace test is that there are $r$ cointegrating equations, and the alternative hypothesis is that there are $k$. Here, $k$ is the number of endogenous variables and $r k$. For the maximum-eigenvalue test, the null hypothesis is that there are $r$ cointegrating equations. The alternative hypothesis for this test is that there are $r+1$ cointegrating equations. In both tests, as we move from testing $r=1,2, \ldots, k$, the decision rule is that we accept the first null hypothesis that is not rejected. If there is cointegration, with both test results not being incongruous, then we estimate a well-specified VECM from which we also carry out Granger causality testing. For a well-specified VECM, the residuals must be serial uncorrelated and multivariate normally distributed. In addition, the VECM must be dynamically stable. In this case, we require that the VECM has $k-r$ eigenvalues in modulus being greater than one. 
Table 2 Unit root test with intercept and trend

\begin{tabular}{lcc}
\hline Variable & ADF & PP \\
\hline LNRE & -3.15 & $-4.19 * *$ \\
$\Delta$ LNRE & $-8.68^{* * *}$ & $-13.97 * * *$ \\
LNREM & -1.87 & -1.27 \\
$\Delta$ LNREM & $4.40^{* * *}$ & $-4.29 * * *$ \\
LNGDP & 1.04 & 1.08 \\
$\Delta$ LNGDP & $-7.77 * * *$ & $-7.56 * * *$ \\
\hline
\end{tabular}

(1) $* * *$ and $* *$ indicate significance at the 1 percent and 5 percent level, respectively. (2) The null hypothesis of the ADF and PP test is that the series has a unit root

\subsection{On the usage of VAR and VECM}

Standard VAR models are advantageous for teasing out the dynamic behavior or variables without the necessity to impose restrictions on which variables are endogenous or exogenous. This is because all the main variables in the VAR are treated symmetrically through an equation-by-equation system. In addition, VAR models have the advantage of being more parsimonious than traditional structural models. While not within the scope of the current paper, VAR models are also advantageous as they are generally able to produce better forecasts than complex univariate and theoretically driven simultaneous based models. This advantage is partly linked to how forecasts from VAR for specific variables can be made conditional of the conditional potential future path of other variables.

Notwithstanding the aforementioned advantages of the standard VAR models, one limitation of these models for forecasting-related causal analysis is that potentially useful information about the dynamics among the variables is lost if the variables are cointegrated. This is because the VAR representation does not account for the joint dynamically behavior of the short-run and long-run responses among the variables. In this case, the representation of the interactions among the variables in a VECM improves upon the characterization of causal inferences among the variables and by extension any sort of forecasting that may take place. Therefore, in our paper, we consider both the standard VAR, a lag-augmented one, and decide as to whether there is also a cointegrating relationship among the variables. The VECM is in effect an equation system of a cointegrated VAR that is formed based on Granger's representation theorem (Engle and Granger, 1987). 
Table 3 ADF break-point unit root test with intercept and trend

\begin{tabular}{lll}
\hline Variable & ADF & Breakpoint \\
\hline LNRE & -3.84 & 1983 \\
$\Delta$ LNRE & $-9.51^{* * *}$ & 1986 \\
LNREM & -3.73 & 2004 \\
$\Delta$ LNREM & $-4.98^{* *}$ & 2012 \\
LNGDP & -0.83 & 2005 \\
$\Delta$ LNGDP & $-8.05^{* * *}$ & 1988 \\
\hline
\end{tabular}

(1) $* * *$ and $* *$ indicate significance at the 1 percent and 5 percent level, respectively. (2) The null hypothesis of the ADF break-point test is that series has a unit root with a break in intercept and innovational outlier

\begin{tabular}{lll}
\hline Lag & LRE statistic & Rao F-statistic \\
\hline 1 & 8.81 & 1.00 \\
2 & 7.75 & 0.87 \\
3 & 9.14 & 1.05 \\
4 & 12.87 & 1.56 \\
5 & 7.14 & 0.79 \\
\hline
\end{tabular}

(1) null hypothesis: no serial correlation at lag order indicated. (2) The Edgeworth expansion corrected likelihood ratio statistic (LRE) and Rao F-statistics both indicate no serial correlation at the 10 percent level of statistical significance or less

\section{Empirical findings}

We present the standard ADF and PP unit root results in Table 2 where trend and intercept data generating processes are specified. ${ }^{4}$ Both tests show that the null hypothesis of the presence of unit roots is not rejected for LNREM and LNGDP. On the other hand, this null hypothesis is rejected at the $1 \%$ level for the first differences of these variables. Therefore, both $L N R E M$ and $L N G D P$ are non-stationary at levels but stationary at their first differences. Regarding $L N R E$, the ADF test establishes that this variable is non-stationary at level but stationary at first difference. The PP unit root test indicates that $L N R E$ is stationary at level and first difference.

As standard unit root tests may yield misleading results if a series has a structural break, we also report the ADF break-point unit root tests for the variables. These results are shown in Table 3 . In this table, the break points and test statistics associated with the null hypothesis that series has a unit root with a break in intercept

\footnotetext{
4 The intercept only and no intercept and trend specifications were also carried out. The conclusions of the test were unchanged, and thus, the more general data generating process is specified here.
} 


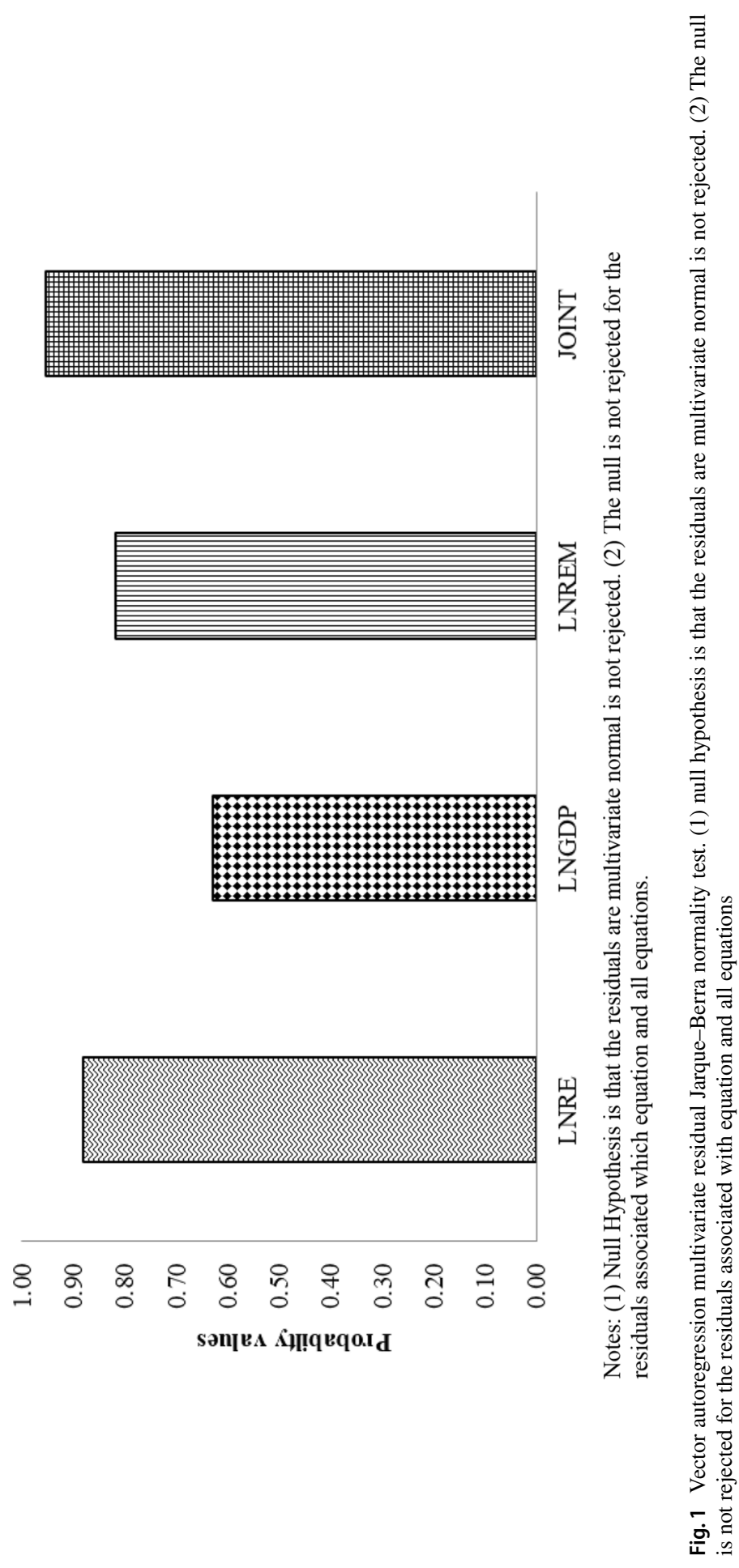




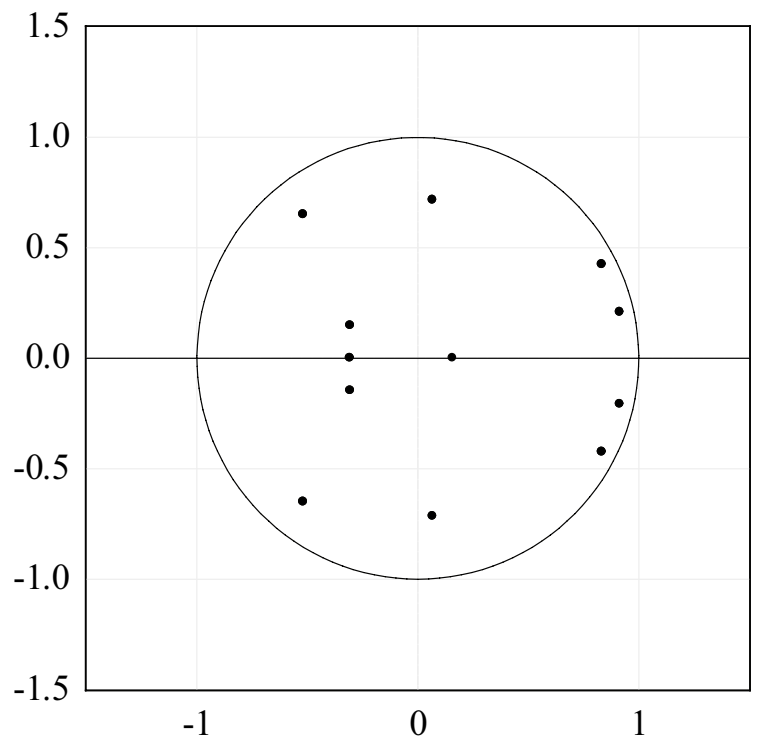

Notes: (1) "dots" are eigenvalues. (2) Solid line is unit circle.

(3) All eigenvalues in modulus are $<1$. (4) stability is satisfied.

Fig. 2 Vector autoregression stability: eigenvalue roots. (1) "dots" are eigenvalues. (2) Solid line is unit circle. (3) All eigenvalues in modulus are $<1$. (4) Stability is satisfied

Table 5 Toda and Yamamoto vector autoregression causality tests

\begin{tabular}{llll}
\hline Dependent variable & Excluded & Chi-squared $\left(\chi^{2}\right)$ & Probability \\
\hline LNRE & LNGDP & $11.46^{* * *}$ & 0.022 \\
& LNREM & $17.11^{* * *}$ & 0.001 \\
& All & $28.12^{* *}$ & 0.000 \\
LNGDP & LNRE & 4.07 & 0.397 \\
& LNREM & 1.98 & 0.739 \\
& All & $5.24 * * *$ & 0.732 \\
LNREM & LNRE & 6.96 & 0.138 \\
& LNGDP & 2.78 & 0.595 \\
& All & $13.39 *$ & 0.099 \\
\hline
\end{tabular}

$* * *, * *$, and $*$ indicate statistical significance at the 1 percent, 5 percent, and 10 percent level, respectively, that the indicated variable should not be excluded

and innovational outlier (gradual change in the trend function) are reported. ${ }^{5}$ While we find that there are structural breaks associated with each variable, the results from this table are consistent with the standard ADP and PP unit root tests. This

\footnotetext{
5 We also tested for break in intercept and trend as well as an additive outlier specification. The results from these additional tests also showed that the log levels of the variables were integrated of order one.
} 
Table 6 Johansen multivariate cointegration test results

\begin{tabular}{lllll}
\hline Variables & $\begin{array}{l}\text { Cointegrating } \\
\text { equations }(r)\end{array}$ & Eigenvalue & Trace statistic & $\begin{array}{l}\text { Maximum- } \\
\text { eigen } \\
\text { statistic }\end{array}$ \\
\hline LNRE, LNGDP, LNREM & $r=0$ & 0.76 & $42.92^{* *}$ & $25.82^{* *}$ \\
& $r \leq 1$ & 0.41 & 25.87 & 19.38 \\
& $r \leq 2$ & 0.13 & 12.52 & 12.52 \\
\hline
\end{tabular}

** indicates that the trace and maximum-eigenvalue test statistics provide evidence in favor of 1 cointegrating equation at 5 percent level of statistical significance

conclusion is that the logarithmic levels of remittances, GDP per capita, and renewable energy consumption are integrated of order one.

Now, we turn to estimate a VAR. We choose one that has four endogenous (the first $p$ lags) lags and one (the last $d$ lag) exogenous. This is the VAR that is internally valid. The full VAR is reported in the appendix Table 9 for the interested reader. Here, we discuss the validity statistics related to the VAR, as the causality tests that follow depend crucially on them. Table 4 reports the Langrage multiplier test for serial correlation that is assessed on the basis of the Edgeworth expansion corrected likelihood ratio statistic (LRE) and Rao F-statistics. These statistics indicate that the null hypothesis of no serial correlation is not rejected at conventional levels of statistical significance. The Jarque-Berra test results of multivariate normality of the residual are reported in Fig. 1. From this figure, we do not reject the null hypothesis that the residuals are multivariate normally distributed as the probability values associated with the test statistics for all higher than the conventional levels of statistical significance. This is true for each equation of the system and the system as a whole. In Fig. 2, we assess the stability of the VAR model. From this figure, we observe that all eigenvalues in modulus are less than one and, thus, the estimated VAR model is stable.

Having established the internal validity of the VAR, we can proceed to the Toda-Yamamoto causality testing. Table 5 reports these results. From this table, in the $L N R E$ equation, $L N G D P$ and $L N R E M$ individually and jointly cause $L N R E$. These causal relationships are statistically significant at the $5 \%$ level or less. From the $L N G D P$ equation, neither $L N R E$ nor $L N R E M$ cause $L N G D P$. Similarly, in the LNREM equation, neither $L N G D P$ nor $L N R E$ cause $L N R E M$. Thus, we find evidence of two-level unidirectional-level relationships: from $L N G D P$ to $L N R E$ and from $L N R E M$ to $L N R E$. These results have two important implications for Bangladesh. First, these results of unidirectional causality from $L N G D P$ to $L N R E$ echo the previous findings by Mozumder and Marathe (2007) for electricity consumption, Paul and Uddin (2011) for total energy consumption, and Das et al. (2013) for natural gas consumption. It is evident that, in Bangladesh, energy consumption (whether renewable or non-renewable) does not necessarily cause economic 
Table 7 Vector error correction model serial correlation Lagrange multiplier test

\begin{tabular}{lll}
\hline Lag & LRE statistic & Rao F-statistic \\
\hline 1 & 5.10 & 0.55 \\
2 & 11.95 & 0.62 \\
3 & 18.38 & 0.58 \\
4 & 29.70 & 0.64 \\
5 & 47.78 & 0.66 \\
\hline
\end{tabular}

Note: (1) Null hypothesis: no serial correlation at lag order indicated. (2) The Edgeworth expansion corrected likelihood ratio statistic (LRE) and Rao F-statistics both indicate no serial correlation at the $10 \%$ level of statistical significance or less

growth. Thus, we believe that conversation policy is still important for this country. Second, there is evidence of unidirectional causality from $L N R E M$ to $L N R E$. In contrast, Das and McFarlane (2020) found that, in the long run, the causal relationships between disaggregated energy consumption and remittances are either bidirectional or unidirectional running from energy to remittances. Therefore, we can argue that remittances are used differently for renewable and non-renewable energy consumption.

As noted earlier, causality does not imply that the variables are cointegrated. However, if there are cointegrating relationships among variables, then there must be either unidirectional or bidirectional causality among those variables. A finding of cointegration, thus, reinforces the VAR causality results. With this in mind, we use the Johansen cointegration test to determine if the causality tests obtained so far can be reinforced. Results from the Johansen test are presented in Table 6. Both trace and maximum-eigenvalue statistics establish the presence of one cointegrating relationship. We conclude that there is a unique long-run cointegrating equilibrium relationship between $L N R E, L N G D P$, and LNREM. The results from the causality tests are reinforced.

Next, we report the Granger causality tests within the VECM framework. These come from estimating a well-specified VECM model. ${ }^{6}$ For this VECM, Table 7 and Fig. 3 report the serial correlation and multivariate normality tests for the residuals, respectively. From Table 7, the langrage multiplier LRE and Rao F-statistics indicate that there is no evidence of serial correlation at conventional levels of statistical significance. From Fig. 3, the Jarque-Bera test shows that the residuals are multivariate normally distributed. Figure 4 shows the eigenvalues in modulus of the VECM. With one cointegration vector and three variables, we require that there be two eigenvalues in modulus greater than one for the VECM to stable. As seen from this figure, this condition is satisfied as there are two eigenvalues in modulus greater than one.

With a well-specified VECM model, we can proceed to Granger causality testing using the VECM. Table 8 reports these results. These results are obtained from

\footnotetext{
${ }^{6}$ Because of space constraints, these results are omitted but are available upon request.
} 


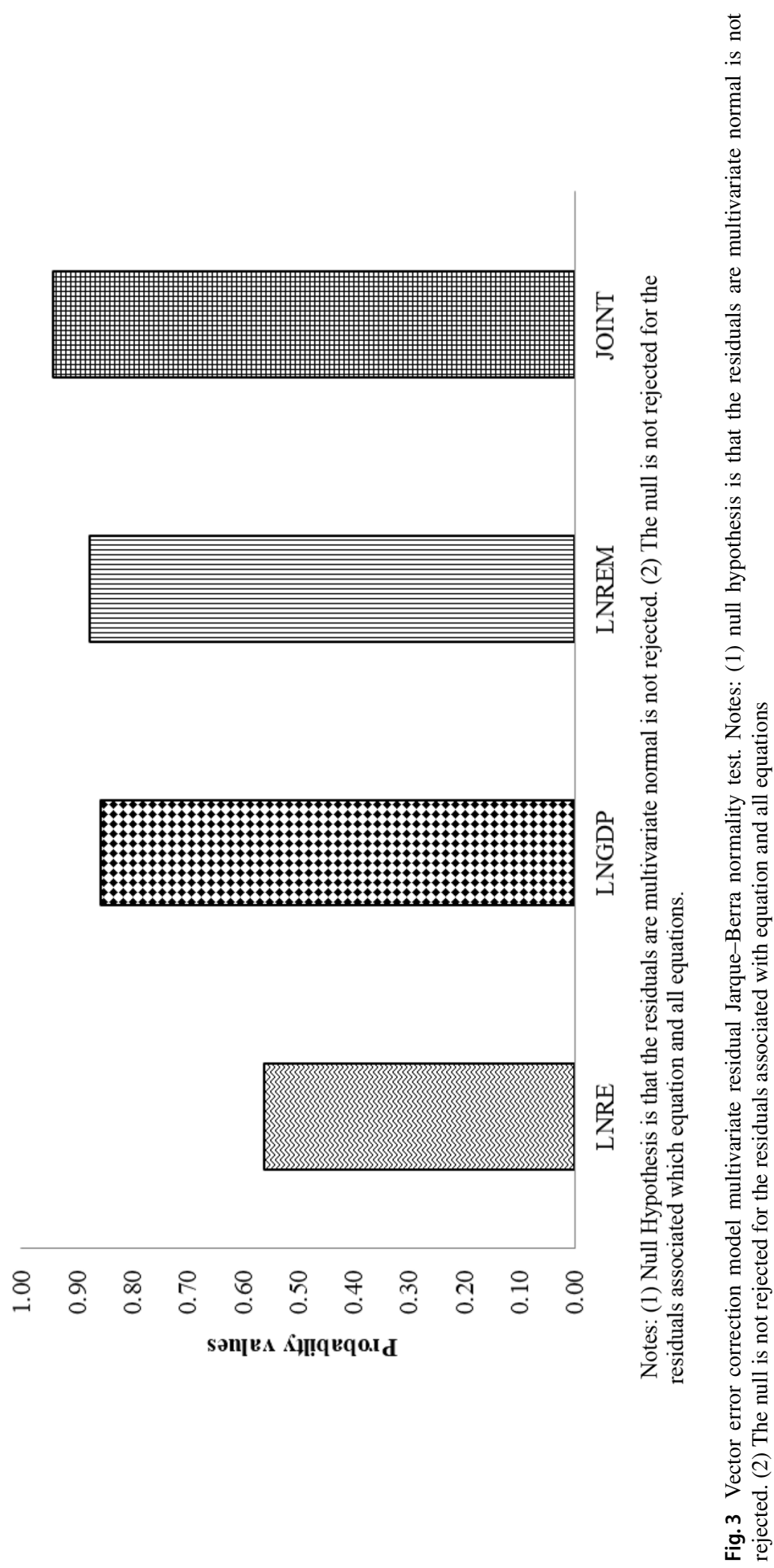




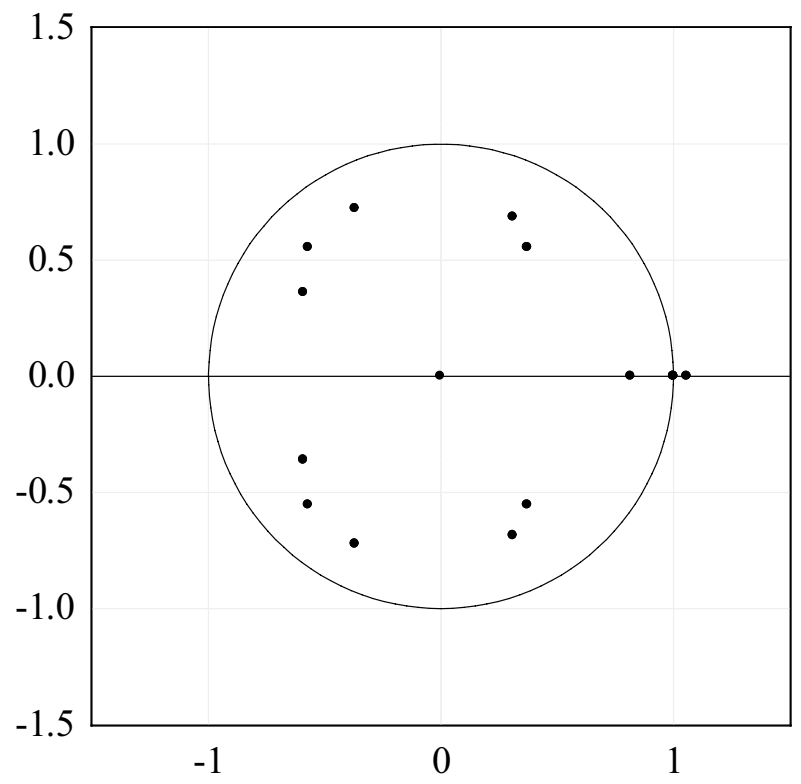

Notes: (1) "dots" are eigenvalues. (2) Solid line is unit circle.

(3) 2 eigenvalues in modulus is $\geq 1$. (4) stability is satisfied.

Fig. 4 Vector error correction model stability: eigenvalue roots. (1) "dots" are eigenvalues. (2) Solid line is unit circle. (3) 2 eigenvalues in modulus is $\geq 1$. (4) Stability is satisfied

Table 8 Vector error correction model Granger causality tests

\begin{tabular}{llll}
\hline Dependent variable & Excluded & Chi-squared $\left(\chi^{2}\right)$ & Probability \\
\hline$\Delta$ LNRE & $\Delta$ LNGDP & $9.28^{*}$ & 0.054 \\
& $\Delta$ LNREM & $12.22^{* *}$ & 0.016 \\
$\Delta$ LNGDP & All & $18.14 * *$ & 0.020 \\
& $\Delta$ LNRE & 2.44 & 0.656 \\
$\Delta$ LNREM & $\Delta$ LNREM & 1.59 & 0.811 \\
& All & 8.18 & 0.416 \\
& $\Delta$ LNRE & $9.51 * *$ & 0.050 \\
& $\Delta$ LNGDP & $11.13 * *$ & 0.025 \\
& All & $15.72 * *$ & 0.047
\end{tabular}

$* *$ and * indicate statistical significance at the 5 and $10 \%$ level, respectively, that the indicated variable should not be excluded

the variables at their first differences. In other words, Granger tests within VECM framework produce short-run causal relationships between variables. From these results, we find evidence of short-run bidirectional causal relationships between LNRE and LNGDP, and LNRE and LNREM. Thus, in the short run, we find evidence of a feedback effect between remittances and renewable energy consumption. 
Further discussion on these results and their importance for Bangladesh are provided in the next section.

\section{Conclusion, policy recommendations and future research}

The empirical literature on the relationship between remittances and energy consumption in developing countries is scarce. Our goal in this paper is to augment the existing literature by determining the nature of the causal relationship between remittances and renewable energy consumption in Bangladesh while controlling for changes in the macroeconomic environment over the period 1980-2017. To our knowledge, this paper is the first of a kind to study the statistical associations between these variables. Bangladesh is one of the largest remittance-recipient countries in the world. At the same time, Bangladesh has also created the world's largest national off-grid electrification program using renewable energy sources. The country's success in promoting the use of renewable energy sources and simultaneously attracting international remittances has made Bangladesh an intriguing case study. We apply the Toda-Yamamoto causality tests, Johansen cointegration tests, and Granger causality tests within a multivariate error correction framework.

The main results are threefold. First, there is evidence of a unidirectional causality from remittances per capita to renewable energy consumption, in terms of the levels of the variables. Second, the results indicate that there is a unique longrun relationship between remittances per capita, renewable energy consumption, and GDP per capita. Third, the results show that there is evidence of bidirectional causality between remittances to renewable energy consumption in the short run. Perhaps, remittance-recipient households use the additional income to purchase renewable energy; the latter is generally viewed as being expensive. This finding supports the anecdotal evidence aforementioned that increasing remittance inflows in Bangladesh generates the additional demand for modern renewable technology such as solar home systems. The short-run bidirectional causality speaks in favor of the feedback hypothesis, where remittances cause the demand for renewable energy and vice versa. In other words, households that use renewable energy demand remittances to finance the purchase. Concomitantly, households that receive remittances also increase their renewable energy consumption. Therefore, it can be argued that at least in the short-run remittances and renewable energy consumption reinforce each other.

To our view, these results are of policy importance. There is no debate in the literature that the overall macroeconomic impact of remittances is positive in Bangladesh. Additionally, we show that remittances create a demand for renewable energy consumption in this country. Therefore, it is important that policymakers create incentives for both senders and recipients of remittances. In this regard, the government can ease the structural barriers and improve the banking system to encourage remittance flows to Bangladesh. The government should consider establishing branches of Bangladeshi banks in foreign cities that have a large Bangladeshi 
Diaspora. According to the latest available data from the World Bank (2020), the average cost of sending remittances to Bangladesh in 2017 was approximately $4.42 \%$ of the amount sent for sending USD 200. A part of this cost is due to various charges levied by the Bangladeshi government. The Sustainable Development Goals of the World Bank calls for reducing transaction costs of migrant remittances to less than $3 \%$. These policies will create incentives for senders to increase remittances to their home country.

Furthermore, the government should also consider creating incentives for remittance-recipient households. For example, to encourage the development of more off-grid solar home systems out of remittance income, the government can match the remittance contributions. This will not only reduce the cost for households to build the solar home systems, but also reduce the dependence on non-renewable energy sources, which are not generally environment friendly. To promote the use of cleaner technology, the government should provide subsidies to poor households who otherwise cannot afford the consumption of modern renewable energy. Remittances to a home country are often determined by exogenous factors including economic growth in the host countries, exchange rates, and interest and price differentials between the home and host countries. In the case of a decline in economic activity in host countries, it is likely that the future flow of remittances will fall. ${ }^{7}$ In such a situation, the overall consumption pattern (including energy consumption) is likely to fall in remittance-recipient countries like Bangladesh. Thus, the government should take these external factors into consideration and create policies to continue with modern renewable energy projects even in a period of worldwide economic downturns. These policy implications are important not only for Bangladesh but also for other remittance-recipient developing countries that struggle to meet the domestic demand from energy from traditional sources.

The empirical examinations conducted in our paper are based on a few statistical assumptions. Nonetheless, we provide an analysis that shows the causal dynamics between remittance and renewable energy consumption in Bangladesh. We contend that there are several opportunities for future research to have a better understanding of these dynamics. First, future research should use household-level micro data to examine if the behavior of remittance-recipient households in regard to renewable energy consumption is different from non-remittance-recipient households. This will help policymakers design policies for cleaner energy use for all households in the country. Second, numerous studies examined the impact of disaggregated nonrenewable energy consumption in developing countries. However, data on disaggregated renewable energy consumption are not readily available for most developing countries including Bangladesh. With the availability of data, future research should focus on the causal dynamics between remittances and disaggregated renewable energy consumption. Third, an important objective of future research is to examine the relationship between remittances and renewable energy production.

\footnotetext{
7 There is a possibility for a fall in remittances due to the evolving COVID-19 situation.
} 


\section{Appendix}

See Table 9.

Table 9 Vector autoregression results

\begin{tabular}{|c|c|c|c|}
\hline & $\mathrm{LNRE}_{t}$ & LNGDP & $\mathrm{LNREM}_{t}$ \\
\hline \multicolumn{4}{|l|}{ Endogenous } \\
\hline $\mathrm{LNRE}_{t-1}$ & $-0.23(0.25)$ & $0.02(0.01)^{* * *}$ & $0.28(0.14)^{* * *}$ \\
\hline $\mathrm{LNRE}_{t-2}$ & $0.08(0.23)$ & $0.01(0.01)^{*}$ & $0.19(0.13)^{* *}$ \\
\hline $\mathrm{LNRE}_{t-3}$ & $-0.10(0.18)$ & $0.00(0.01)$ & $\left(\begin{array}{ll}0.01 & 0.10\end{array}\right)$ \\
\hline $\mathrm{LNRE}_{t-4}$ & $-0.14(0.17)$ & $0.00(0.01)$ & $(0.120 .10)^{*}$ \\
\hline $\operatorname{LNGDP}_{t-1}$ & $1.15(5.62)$ & $1.05(0.24)^{* * *}$ & $-0.75(3.12)$ \\
\hline $\operatorname{LNGDP}_{t-2}$ & $-10.73(8.30)^{*}$ & $-0.02(0.35)$ & $4.42(4.60)$ \\
\hline $\mathrm{LNGDP}_{t-3}$ & $-7.95(7.50)$ & $0.19(0.32)$ & $-2.07(4.16)$ \\
\hline LNGDP $_{t-4}$ & $9.46(6.44)^{* *}$ & $-0.30(0.27)$ & $2.15(3.57)$ \\
\hline LNREM $_{t-1}$ & $0.72(0.46)^{* *}$ & $-0.02(0.02)$ & $1.02(0.25)^{* * *}$ \\
\hline LNREM $_{t-2}$ & $0.31(0.60)$ & $0.00(0.03)$ & $-0.62(0.33)^{* *}$ \\
\hline LNREM $_{t-3}$ & $-1.05(0.58)^{* *}$ & $0.01(0.02)$ & $0.47(0.32)^{* *}$ \\
\hline LNREM $_{t-4}$ & $-0.34(0.54)$ & $0.01(0.02)$ & $0.08(0.30)$ \\
\hline \multicolumn{4}{|l|}{ Exogenous } \\
\hline Intercept & $-32.66(8.32)^{* * *}$ & $0.18(0.35)$ & $10.23(4.62)^{* * * *}$ \\
\hline $\mathrm{LNRE}_{t-5}$ & $0.27(0.21)^{*}$ & $0.02(0.01)^{* * *}$ & $0.07(0.12)$ \\
\hline $\operatorname{LNGDP}_{t-5}$ & $13.09(6.57)^{* * * *}$ & $0.09(0.28)$ & $-4.99(3.64)$ \\
\hline LNREM $_{t-5}$ & $-0.64(0.45)^{*}$ & $0.01(0.02)$ & $0.24(0.25)^{*}$ \\
\hline Adj. $R$-squared & 0.529 & 0.999 & 0.985 \\
\hline $\begin{array}{l}\text { Akaike Information } \\
\text { criterion }\end{array}$ & -0.262 & -6.573 & -1.441 \\
\hline Observations & 48 & 48 & 48 \\
\hline
\end{tabular}

(1) standard errors are in parentheses; (2) ***, **, and * indicate statistical significance at the 1, 5, and $10 \%$ level, respectively; (3) lag-augmented VAR with 4 endogenous lags and 1 exogenous lag

\section{References}

Adams R, Cuecuecha A (2013) The impact of remittances on investment and poverty in Ghana. World Dev 50(October):24-40

Ahamad MG, Islam AKMN (2011) Electricity consumption and economic growth nexus in Bangladesh: revisited evidences. Energy Policy 39(10):6145-6150

Akçay S (2020) Remittances and financial development in Bangladesh: substitutes or complements? Appl Econ Lett 27(14):1206-1214

Akçay S, Demirtaş G (2015) Remittances and energy consumption: evidence from Morocco. Int Migr 53(6):125-144

Akter S (2018) Do remittances and foreign aid augment the gross savings: Bangladesh, India and Philippines perspectives? Int Rev Econ 65(4):449-463 
Alam MJ, Ahmed M, Begum IA (2017) Nexus between non-renewable energy demand and economic growth in Bangladesh: application of maximum entropy bootstrap approach. Renew Sustain Energy Rev 72(May):399-406

Alam MJ, Begum IA, Buysee J, Huylenbroeck GV (2012) Energy consumption, carbon emissions and economic growth nexus in Bangladesh: cointegration and dynamic causality analysis. Energy Policy 45(June):217-225

Alam K, Sarker AR (2010) Nexus between electricity generation and economic growth in Bangladesh. Asian Social Sci 6(12):16-22

Al-Mulali U, Fereidouni H, Lee J, Sab CNBC (2013) Examining the bi-directional long run relationship between renewable energy consumption and GDP growth. Renew Sustain Energy Rev 22(June):209-222

Alper A, Oguz O (2016) The role of renewable energy consumption in economic growth: evidence from asymmetric causality. Renew Sustain Energy Rev 60(July):953-959

Amri F (2017) The relationship among energy consumption (renewable and non-renewable), and GDP in Algeria. Renew Sustain Energy Rev 76(September):62-71

Apergis N, Payne JE (2014) The causal dynamics between renewable energy, real GDP, emissions and oil prices: evidence from OECD countries. Appl Econ 46(36):4519-4525

Apergis N, Payne JE (2012) Renewable and non-renewable energy consumption-growth nexus: evidence from a panel error correction model. Energy Econ 34(3):733-738

Apergis N, Payne JE (2011) The renewable energy consumption-growth nexus in Central America. Appl Energy 88(1):343-347

Apergis N, Payne JE (2010) Renewable energy consumption and growth in Eurasia. Energy Econ 32(6):1392-1397

Azam M (2015) The role of migrant workers remittances in fostering economic growth: the four Asian developing countries' experiences. Int J Social Econ 42(8):690-705

Barai MK (2012) Developmental dynamics of remittances in Bangladesh. Sage Open 2(1):1-13

Benali N, Feki R (2020) Evaluation of the relationship between freight transport, energy consumption, economic growth and greenhouse gas emissions: the VECM approach. Environ Dev Sustain 22(2):1039-1049

Ben-Salha O, Sebri M (2014) A multivariate analysis of the causal flow between renewable energy consumption and GDP in Tunisia. Econ Bull 34(4):2396-2410

Bhattacharya M, Paramati SR, Ozturk I, Bhattacharya S (2016) The effect of renewable energy consumption on economic growth: Evidence from top 38 countries. Appl Energy 162(January):733-741

Borozan D (2013) Exploring the relationship between energy consumption and GDP: evidence from Croatia. Energy Policy 59(August):373-381

Bowden N, Payne JE (2010) Sectoral analysis of the causal relationship between renewable and nonrenewable energy consumption and real output in the US. Energy Sour Part B 5(4):400-408

Bulut U, Muratoglu G (2018) Renewable energy in Turkey: great potential, low but increasing utilization, and an empirical analysis on renewable energy-growth nexus. Energy Policy 123(December):240-250

Chen C, Pinar M, Stengos T (2020) Renewable energy consumption and economic growth nexus: evidence from a threshold model. Energy Policy 139(April):111295

Chen Y, Zhao J, Lai Z, Wang Z, Xia H (2019) Exploring the effects of economic growth, and renewable and non-renewable energy consumption on China's $\mathrm{CO} 2$ emissions: evidence from a regional panel analysis. Renew Energy 140(September):341-353

Chimhowu A, Piesse J, Pinder C (2005) The socioeconomic impact of remittances on poverty reduction. In: Maimbo S, Ratha D (eds) Remittances: development impact and future prospects, Chapter 3. The World Bank, Washington, DC, pp 83-102

Chowdhury M (2011) Remittance flow and financial development in Bangladesh. Econ Model 28(6):2600-2608

Chowdhury M, Rabbi F (2014) Workers' remittances and Dutch disease in Bangladesh. J Int Trade Econ Dev 23(4):455-475

Clarke JA, Mirza S (2006) A comparison of some common methods for detecting Granger noncausality. J Stat Comput Simul 76:207-231

Das A (2012) Remittance behaviour of migrants and its macroeconomic effects in four developing countries. Int J Appl Behav Econ 1(1):41-59

Das A, Chowdhury M (2019) Macroeconomic impacts of remittances in Bangladesh: the role of reverse flows. Econ Notes 48(3):e12139 
Das A, McFarlane A (2020) Remittances and disaggregated energy consumption in Bangladesh. Int Rev Econ 67:251-268

Das A, McFarlane A, Chowdhury M (2013) The dynamics of natural gas consumption and GDP in Bangladesh. Renew Sustain Energy Rev 22:269-274

Dey SR, Tareque M (2019) Electricity consumption and GDP nexus in Bangladesh: a time series investigation. J Asian Bus Econ Stud 27(1):35-48

Dolado JJ, Lütkepohl H (1996) Making Wald tests work for cointegrated VAR systems. Econom Rev 15(4):369-386

Engle RF, Granger CWJ (1987) Co-integration and error correction: representation estimation and testing. Econometrica 55(2):251-276

Glytsos NP (2002) The role of migrant remittances in development: Evidence from Mediterranean countries. Int Migr 40(1):5-25

Glytsos NP (1993) Measuring the income effects of migrant remittances: a methodological approach applied to Greece. Econ Dev Cult Change 42(1):131-168

Government of Bangladesh (2008) Renewable Energy Policy of Bangladesh. The Government of the People's Republic of Bangladesh, Dhaka. Available at: http://www.sreda.gov.bd/d3pbs_uploads/files /policy_1_rep_english.pdf. Accessed 19 Mar 2020

Hasan M (2008) The macroeconomic determinants of remittances in Bangladesh. Institute of Microfinance. Available at: http://mpra.ub.uni-muenchen.de/27744/. Accessed 19 Mar 2020

Hassan G, Chowdhury M, Bhuyan M (2016) Growth effects of remittances in Bangladesh: Is there a U-shaped relationship? Int Migr 54(5):105-121

Hossain MS, Arshad M, Qian L, Kächele H, Khan I, Islam MDI, Mahboob MG (2020) Climate change impacts on farmland value in Bangladesh. Ecol Ind 112(May):106181

Hossain AN, Hasanuzzaman S (2013) Remittances and investment nexus in Bangladesh: an ARDL bounds testing approach. Int Rev Econ 60(4):387-407

Inglesi-Lotz R (2016) The impact of renewable energy consumption to economic growth: a panel data application. Energy Econ 53:58-63

International Federation of Red Cross and Red Crescent Societies (2018) World Disasters Report 2018. International Federation of Red Cross and Red Crescent Societies, Geneva. Available at: https://media.ifrc.org/ifrc/wp-content/uploads/sites/5/2018/10/B-WDR-2018-EN-LR.pdf. Accessed 19 Mar 2020

International Fund for Agricultural Development (2016) Remittances, investments and the Sustainable Development Goals. Available at: https://www.ifad.org/documents/38714170/39148759/ Remittances\%2C+investments+and+the+Sustainable+Development+Goals.pdf/680f2e3f-38dc42c2-9857-df9580d35a45. Accessed 19 Mar 2020

Islam, S. (2018). With solar farms and roof panels, Bangladesh inches toward green power goal. Reuters, October 15, 2018. Available at: https://www.reuters.com/article/us-bangladesh-renewables -climatechange/with-solar-farms-and-roof-panels-bangladesh-inches-toward-green-power-goalidUSKCN1MQ05I

Iyke BN (2015) Electricity consumption and economic growth in Nigeria: a revisit of the energygrowth debate. Energy Econ 51:166-176

Khan Z, Islam S (2013) The effects of remittances on inflation: evidence from Bangladesh. J Econ Bus Res XIX(2):198-208

Khandker SR, Samad HA, Sadeque ZKM, Asaduzzaman M, Yunus M, Haque AKE (2014) Surge in solar powered homes: Experience in off-grid rural Bangladesh. The World Bank, Washington, DC. Available at: http://documents.worldbank.org/curated/en/871301468201262369/pdf/Surge -in-solar-powered-homes-experience-in-off-grid-rural-Bangladesh.pdf. Accessed 19 Mar 2020

Kula F (2014) The long-run relationship between renewable electricity consumption and GDP: evidence from panel data. Energy Sources Part B 9(2):156-160

Kumar RR, Stauvermann PJ (2014) Exploring the nexus between remittances and economic growth: a study of Bangladesh. Int Rev Econ 61(4):399-415

Mahalingam B, Orman W (2018) GDP and energy consumption: a panel analysis of the US. Appl Energy 213(March):208-218

Mahmud, F. (2016). A solar revolution is bringing light and opportunity to the Bangladeshi countryside. The Discourse, April 19, 2016. Available at: https://thediscourse.ca/energy/solar-revolution -bringing-light-opportunity-bangladeshi-countryside

Mamun K, Nath H (2010) Workers' migration and remittances in Bangladesh. J Bus Strateg 27(1):29-52 
Masuduzzaman M (2012) Electricity consumption and economic growth in Bangladesh: co-integration and causality. Glob J Manag Bus Res 12(11):46-56

Mendelson S (2013) Sustainable energy access for the poor. Americas Quarterly Online. Available at: www.americasquarterly.org/content/sustainable-energy-access-poor. Accessed 19 Mar 2020

Menegaki AN (2011) Growth and renewable energy in Europe: a random effect model with evidence for neutrality hypothesis. Energy Econ 33(2):257-263

Menegalo A, Ozturk I (2016) Renewable energy, rents and GDP growth in MENA countries. Energy Sources Part B 11(9):824-829

Menyah K, Wolde-Rufael Y (2010) $\mathrm{CO}_{2}$ emissions, nuclear energy, renewable energy and economic growth in the US. Energy Policy 38(6):2911-2915

Mozumder P, Marathe A (2007) Causality relationship between electricity consumption and GDP in Bangladesh. Energy Policy 35(1):395-415

Nordic Development Fund (2015) Final report: financing sustainable energy through remittances flows to Bolivia. Available at: https://www.ndf.fi/sites/ndf.fi/files/attach/ncf2_gaia_bolivia_final _report_public.pdf

Ocal O, Aslan A (2013) Renewable energy consumption-economic growth nexus in Turkey. Renew Sustain Energy Rev 28(December):494-499

Oh W, Lee K (2004a) Energy consumption and economic growth in Korea: testing the causality relation. J Policy Model 26(8-9):973-981

Oh W, Lee K (2004b) Causal relationship between energy consumption and GDP revisited: the case of Korea 1970-1999. Energy Econ 26(1):51-59

Orozco M (2005) Transnationalism and development: trends and opportunities in Latin America. In: Maimbo S, Ratha D (eds) Remittances: development impact and future prospects, Chapter 15. The World Bank, Washington, DC, pp 83-102

Pao HT, Li YY, Fu HC (2014) Clean energy, non-clean energy, and economic growth in the MIST countries. Energy Policy 67(April):932-942

Paul BP, Uddin GS (2011) Energy and output dynamics in Bangladesh. Energy Econ 33(3):480-487

Paul BP, Uddin GS, Noman AM (2011) Remittances and output in Bangladesh: an ARDL bounds testing approach to cointegration. Int Rev Econ 58(2):229-242

Payne JE (2009) On the dynamics of energy consumption and output in the US. Appl Energy 86(4):575-577

Rahman M (2009) Contributions of exports, FDI and expatriates' Remittances to real GDP of Bangladesh, India, Pakistan and Sri Lanka. Southwestern Econ Rev 36:141-154

Rehman A, Rauf A, Ahmad M, Chandio AA, Deyuan Z (2019) The effect of carbon dioxide emission and the consumption of electrical energy, fossil fuel energy, and renewable energy, on economic performance: evidence from Pakistan. Environ Sci Pollut Res 26(21):21760-21773

Russell SS (1986) Remittances from international migration: a review in perspective. World Dev 14(6):677-696

Sadeque Z, Rysankova D, Elahi R, Soni R (2014) Scaling up access to electricity: the case of Bangladesh. Live Wire, 2014/21, The World Bank. Available at: http://documents.worldbank.org/curat ed/en/699721468003918010/pdf/88702-REPF-BRI-PUBLIC-Box385194B-ADD-SERIES-Livewire-knowledge-note-series-LW21-New-a-OKR.pdf. Accessed 19 Mar 2020

Sadorsky P (2009) Renewable energy consumption and income in emerging economies. Energy Policy 37(10):4021-4028

Saidi K, Mbarek MB (2016) Nuclear energy, renewable energy, CO2 emissions, and economic growth for nine developed countries: evidence from panel Granger causality tests. Prog Nucl Energy 88(April):364-374

Salim RA, Hassan K, Shafiei S (2014) Renewable and non-renewable energy consumption and economic activities: further evidence from OECD countries. Energy Econ 44:350-360

Senbeta A (2013) Remittances and the sources of growth. Appl Econ Lett 20(6):572-580

Shahbaz M, Lean HH (2012) The dynamics of electricity consumption and economic growth: a revisit study of their causality in Pakistan. Energy 39(1):146-153

Siddique A, Selvanathan EA, Selvanathan S (2012) Remittances and economic growth: empirical evidence from Bangladesh, India and Sri Lanka. J Dev Stud 48(8):1045-1062

Stahl CW, Arnold F (1986) Overseas workers' remittances in Asian development. Int Migr Rev 20(4):899-925

Stahl CW, Habib A (1989) The impact of overseas workers' remittances on indigenous industries: evidence from Bangladesh. Dev Econ XXII(3):269-285 
Swiss Agency for Development and Cooperation (2018) Energy, migration and the 2030 agenda for sustainable development, Briefing Note. Available at: https://www.odi.org/sites/odi.org.uk/files/ resource-documents/12301.pdf. Accessed 19 Mar 2020

Tiwari AK (2011) A structural VAR analysis of renewable energy consumption, real GDP and $\mathrm{CO}_{2}$ emissions: evidence from India. Econ Bull 31(2):1793-1806

Toda HY, Phillips PC (1994) Vector autoregression and causality: a theoretical overview and simulation study. Econom Rev 13(2):259-285

Toda HY, Yamamoto T (1995) Statistical inference in vector autoregressions with possibly integrated processes. J Econom 66(1-2):225-250

U.S. Energy Information Administration (2020) International energy statistics. Available at: https:// www.eia.gov/international/overview/country/BGD. Accessed 10 Mar 2020

Yildirim E, Saraç Ş, Aslan A (2012) Energy consumption and economic growth in the USA: evidence from renewable energy. Renew Sustain Energy Rev 16(9):6770-6774

Wang SS, Zhou DQ, Zhou P, Wang QW (2011) CO2 emissions, energy consumption and economic growth in China: a panel data analysis. Energy Policy 39(9):4870-4875

World Bank (2020) World Development Indicators, Washington, DC: The World Bank. Available at: https://data.worldbank.org/. Accessed 10 Mar 2020

World Bank (2019a). Record high remittances sent globally. Press Release, April 8, 2019, The World Bank. Available at: https://www.worldbank.org/en/news/press-release/2019/04/08/record-highremittances-sent-globally-in-2018

World Bank (2019b) Migration and remittances: Recent developments and outlook. Migration and Development Brief, 31. Available at: https://www.knomad.org/sites/default/files/2019-04/Migra tionanddevelopmentbrief31.pdf. Accessed 19 Mar 2020

Zapata HO, Rambaldi AN (1997) Monte Carlo evidence on cointegration and causation. Oxford Bull Econ Stat 59(2):285-298

Publisher's Note Springer Nature remains neutral with regard to jurisdictional claims in published maps and institutional affiliations. 